\title{
Sensory Analyses and Nutritional Qualities of Hand-Made Breads with Organic Grown Wheat Bread Populations
}

\author{
Camille Vindras-Fouillet ${ }^{*}$, Olivier Ranke ${ }^{2}$, Jean-Pierre Anglade ${ }^{3}$, Bruno Taupier-Letage ${ }^{1}$, \\ Chable Véronique ${ }^{4}$, Isabelle Goldringer ${ }^{5}$ \\ ${ }^{1}$ French Research Institute of Organic Farming, Paris, France \\ ${ }^{2}$ Bergerie de Villarceaux, Chaussy, France \\ ${ }^{3}$ Nature \& Progrès, Alès, France \\ ${ }^{4}$ INRA, UR SAD, Rennes, France \\ ${ }^{5}$ CNRS-INRA-UPS-INAPG, UMR Plant Genetic, Gif sur Yvette, France \\ Email: ${ }^{*}$ camille.vindras@itab.asso.fr, bruno.taupier-letage@itab.asso.fr, olivier.ranke@orange.fr, \\ anglade.jean-pierre@wanadoo.fr, Veronique.Chable@rennes.inra.fr, isabelle.goldringer@moulon.inra.fr
}

Received 15 August 2014; revised 4 September 2014; accepted 8 September 2014

Copyright $@ 2014$ by authors and Scientific Research Publishing Inc.

This work is licensed under the Creative Commons Attribution International License (CC BY). http://creativecommons.org/licenses/by/4.0/

(c) (i) Open Access

\section{Abstract}

Population varieties can meet the needs of organic farming as they are composed of diverse genotypes and have nutritional and sensory characteristics of interest. Their intra-specific genetic variability helps to adapt to the diversity of soil and climate conditions, management practices and needs. Moreover, an integrated organic bread sector has emerged willing to use more wheat populations. To explore sensory and nutritional potential of bread wheat populations, hedonic tests, sensory profile and nutritional analyses were implemented on eight wheat population varieties and one modern variety. Hedonic tests revealed consensus among consumer when ranking according to specific sensory characteristics and showed preferences for red wheat breads. Descriptive sensory test showed significant differences between genotypes on 6 out of 11 descriptors and confirmed the sensory specificity of red wheat accessions. Nutritional analyses showed differences especially on minerals content. Sensory differences between breads from different genotypes can be perceived both by trained and untrained panels as suggested by results. Moreover, red accessions showed specific sensory characteristics which are well-perceived by the two panels. Breeding effort should be maintained for high diverse genotypes with improved sensory and nutritional qualities adapted to organic farming conditions. Indicators like kernel colour should be sought to help integrate such criteria.

\footnotetext{
${ }^{*}$ Corresponding author.
}

How to cite this paper: Vindras-Fouillet, C., et al. (2014) Sensory Analyses and Nutritional Qualities of Hand-Made Breads with Organic Grown Wheat Bread Populations. Food and Nutrition Sciences, 5, 1860-1874. 


\section{Keywords}

\section{Organic Farming, Sensory Analysis, Bread Wheat, Population Varieties, Nutritional Analysis}

\section{Introduction}

Over the second half of the 20th century, plant breeding has developed varieties adapted to high input farming systems and industrial baking, resulting in the replacement of local varieties, which were potentially adapted to the specific soil and climate conditions of each region and had potentially good bread making properties [1]. Recently, however, agricultural practices more environment-friendly such as organic farming have developed leading to an increased diversity in agronomic, soil and ecological conditions. This, together with the growing demand for diversification in terms of product quality, has generated a need for new varieties, general and specific, which are barely met by the standard model of variety innovation.

Breeding for organic farming should take several criteria into account: adaptation to the local soil and climatic conditions and to pest and pathogen pressures, weed competition, conformity to the organic specification and specifically growing without chemical inputs and pesticides, no genetic modification, acceptable economic profitability and a high level of nutritional and gustatory quality [2]. Modern varieties have been bred to provide high yield under high input agricultural conditions and thus they might lack the robustness and quality characteristics that are required for organic agriculture. Up to now, wheat sensory properties have not been systematically included as qualities parameters in the selection of new wheat varieties. However, the availability of suitable wheat varieties is critical for the development of organic agriculture able to meet demands in terms of nutritional and sensory quality.

Sensory properties are usually measured through sensory methods (descriptive analyses) as instrumental techniques are still limited to predict human perception [3]. The influence of farming system, milling and baking technique including flour type and fermentation [4] [5] and genetic structure [6] [7] on bread sensory properties have been investigated. In order of importance the identified factors are milling technique, baking practice (fermentation type and time, kneading intensity, etc.), genetic structure and finally farming system. To summarize, it seems that stone milled breads, wholegrain breads and organic wheat breads have specific sensory properties which are thought to be due to bran compared to conventional bread or white pan bread [5]. They showed more intense aromas such as roasted cereals, bitterness or a crusty texture.

This brought to light the close linked between nutritional and sensory qualities of wheat bread.

Specific nutritional quality of wheat bread can be defined by a complex set of variables. The quantity and quality of grain protein is a first parameter that defines the textural properties of the bread. Among wheat protein the gliadin is implicated in the dough extensibility. Moreover gliadin is suspected to play a role in gluten sensitivity by acting as inhibitors of alpha-amylase activity in some animals [8]. The pro-vitamin and vitamin content are vital nutrient and their supplementation are important for the treatment of certain health problems. The "antioxidant" hypotheseis that Vitamin E, carotenoids and other antioxidant micronutrients afford protection against chronic disease by decreasing oxidative damage [9]. The predominant carotenoid in wheat is lutein and is suspected to reduce the oxidative damage link to the aging process [10]. Moreover, carotenoid content may affect bread flavour by limiting the development of hexanal, a compound responsible for flavour problems [11]. Minerals content is another source of health benefits. Nevertheless, the availability of minerals depends on phytate content which had a decalcifying effect. On a sensory point of view, alkaline metal such as potassium or alkaline earth such as magnesium may contribute to the taste of wheat bread [12]. Finally the different categories of dietary fibres have shown to benefit diabetes, blood cholesterol level, body weight control and reduction of the risk of coronary heart diseases. Moreover some fibres as pentosan are implicated in the textural properties of bread wheat.

Farmer-bakers in the "Réseau Semences Paysannes" (RSP) network (a network of more than 70 associations aimed at the maintenance of cultivated biodiversity) have identified so called "landraces" (local varieties released before 1840s) and varieties from ancient breeding (varieties that have been released between 1840 and 1960) as a potential source of genetic diversity to breed wheat varieties adapted to their practices and needs. Those two types of varieties have been created before the genetic bottleneck associated with the emergence of 
“formal breeding” (breeding for pure lines) [13]. The genetic variability of population varieties can be expected to improve resilience because of their great adaptation capacity. Moreover, a significant historic evolution on nutritional composition of wheat grain has been observed between pure line varieties and population varieties which suggest that there is a potential for aroma and flavour diversity in population varieties [13]. The farmerbakers from RSP have started to reproduce some of them and are interested in testing their processing in bread.

In this context, a French interdisciplinary research programme, PICRI (Partnership between Institutions and Citizen for Research and Innovation), was launched in 2007 to develop participatory breeding and management methods based on the broad diversity of landraces and historic varieties and to characterize their variability for hedonic, sensory and nutritional quality.

The objective of this work was to assess sensory quality of different wheat varieties and mixtures of varieties and correlate with nutritional analyses of the same sample. Moreover, liking tests have been implemented to check if sensory differences should be perceived and appreciated by consumers as no study on hedonic test on landraces exists [3]. Such information is expected to support the development of a greater diversity of wheat relevant to organic wheat production within an agronomic and social context at a local scale.

\section{Materials and Methods}

\subsection{Wheat Samples and Milling}

Nine landraces and historic varieties and one pure line variety used as a control sample were grown in an experimental field under organic agriculture management in La Bergerie de Villarceau near Paris in France (49.11; 1.718). The wheat grown in 2007-2008 has been used for hedonic assessment whereas the next year's crops (2008-2009) were studied for their sensory and nutritional properties. Trials were repeated three times on plot of $120 \mathrm{~m}^{2}$. Phenotypic measures (not shown in this article) included yield have been realised in order to better characterised genotypes and help breeding process. Grains from replication were pooled before being cleaned and stored in a dry room. After four-month storage, $500 \mathrm{~g}$ of each pooled grain sample were sent to the laboratory for nutritional analyses. At the same time, wheat flour samples were obtained from the stone milling (T80 flour type) of grain samples. The samples evaluated in the different tests are summarized in Table 1.

\subsection{Descriptive Sensory Analysis}

Bread was made by Pierre Delton, a local baker, one day before the sensory evaluation. The same bread dough formula was adopted (water: $70 \%$ of the flour weight; sourdough: 15\%; salt: $2.7 \%$ ) and the same bread making process was followed: hand-kneading (flour, water, sourdough, salt) for $25 \mathrm{~min}$; left to rest at $27^{\circ} \mathrm{C}$ for $4 \mathrm{~h}$; forming ( $1 \mathrm{~kg}$ size loaf); rising at $29^{\circ} \mathrm{C}$ for $3 \mathrm{~h}$, etching of the surface of the bread; baking in a simultaneous way ( $45 \mathrm{~min}$ at $240^{\circ} \mathrm{C}$ ). Breads were sliced (slices $13 \mathrm{~mm}$ thick) ten minute before tasting. Each slice was cut into 5 pieces with each piece including both crust and crumb in order to evaluate the overall sensory characteristics.

Sensory profile training and evaluation took place in a meeting room at the INRA laboratory, Le Moulon. The panel was composed of farmers, bakers, researchers and technicians involved in the project, along with volunteers of the "Nature \& Progrès" association.

An initiation to sensory analysis was carried out at the beginning of the project on a large number of breads produced using endogenous sourdough. This provided diverse product qualities for panellist taste references. A first set of sensory attributes was developed. Two training days at an interval of one week completed the initiation

Table 1. List of wheat samples evaluated in the three experiments (the " $X$ " indicate that the variety (column) has been evaluated in the test correspondant to the line).

\begin{tabular}{cccccccccc}
\hline & $\begin{array}{c}\text { Rouge de } \\
\text { Bordeaux }\end{array}$ & $\begin{array}{c}\text { Rouge } \\
\text { du Roc }\end{array}$ & Odessa & $\begin{array}{c}\text { Mélange } \\
\text { de James }\end{array}$ & $\begin{array}{c}\text { Chiddamd' } \\
\text { automne }\end{array}$ & $\begin{array}{c}\text { 20\% Ile de } \\
\text { France + 80\% } \\
\text { Gâtine }\end{array}$ & Touzelle & Talisman & $\begin{array}{c}\text { Renan } \\
\text { Dattel } \\
\text { (modern } \\
\text { variety) }\end{array}$ \\
\hline $\begin{array}{c}\text { Consumer } \\
\text { test }\end{array}$ & $\mathrm{X}$ & $\mathrm{X}$ & $\mathrm{X}$ & & $\mathrm{X}$ & $\mathrm{X}$ & $\mathrm{X}$ & $\mathrm{X}$ & $\mathrm{X}$ \\
$\begin{array}{c}\text { Sensory } \\
\text { profile }\end{array}$ & $\mathrm{X}$ & & $\mathrm{X}$ & $\mathrm{X}$ & $\mathrm{X}$ & $\mathrm{X}$ & & $\mathrm{X}$ \\
$\begin{array}{c}\text { Nutritional } \\
\text { analyses }\end{array}$ & $\mathrm{X}$ & $\mathrm{X}$ & $\mathrm{X}$ & $\mathrm{X}$ & $\mathrm{X}$ & $\mathrm{X}$ & $\mathrm{X}$ & & $\mathrm{X}$ \\
\hline
\end{tabular}


course. One training day consisted in evaluating a set of loaves based on the descriptor list that was produced during the initiation course and then reduced during the training course. Each of the two training days comprised four sessions lasting one and a half hours. The same samples were evaluated during the sessions of one day. Panellists received feedback on their performance after each session in order to improve and standardise their discriminatory ability as a panel and to reach consensus. The panel agreed unanimously on 11 attributes to constitute a descriptive profile for the bread: appearance (crust colour, crumb colour, air cell size), aroma (wheat bread, roasting cereals), taste (saltiness, bitterness, acidity), texture (crispiness, smoothness) and long lasting taste. A detailed definition was established for each sensory attribute (Table 2). Intensity of the sensory attributes was rated on a discontinuous, structured scale from 0 (very low) to 7 (high).

Two evaluation sessions on a set of 6 bread samples were then organised in order to provide replication and to assess the panel's performance. The design was complete and balanced for the rank and carry-over effects. A random, three-digit code was assigned to each sample.

\subsection{Nutritional Analyses}

Nutritional analyses have been subcontracted to an independent laboratory, Agrobio Rennes (Rennes, France). Grain was stored in an air conditioned-room at $22^{\circ} \mathrm{C}$ between reception and analysis. All samples were then milled in a ball mill just before analysis. The objective of this work was first to characterise genotypes on certain variables linked to nutritional quality of wheat grain. Then correlations between sensory and nutritional variables were studied as the same samples have been evaluated.

A set of ten wheat grain samples was analysed for nutrient content. The choice of nutrient measurements was based on their interest in health as well as technological properties. The following nutrient contents were measured by the Agrobio laboratory in Rennes: protein content, gliadin content, mineral content (MG, Fe, Zn, Se) carotenoid content (lutein, alpha-carotenoid and beta-carotenoid), vitamin B1 and vitamin E content, phytic acid content and soluble and insoluble fibre content. Protein content was measured using the Kjeldahl method, a method for determining the quantity of nitrogen in chemical substances developed by Johan Kjeldahlin (1883). Gliadin content has been measure using ELISA (Enzyme-linked immunosorbent assay) method. The nutritional density was assessed through the mineral content. Mineral content was analysed by Inductively Coupled Plasma Atomic Emission Spectrometry (ICP-AES). ICP-AES is a multi-element method with very good detection power and offering reliable and rapid determination of the analytes. To estimate the availability of minerals, phytic acid content has been measured by titration and compared with the total minerals content (Mg, Zn, Se, Fe). Carotenoid content (lutein, alpha-carotenoid and beta-carotenoid), vitamin B1 and vitamin E content have been measured using High Performance Liquid Chromatography (HPLC). HPLC is the most frequently used

Table 2. Sensory attributes, description and results of sensory profiles (NS: Non Significant).

\begin{tabular}{cllc}
\hline Sensory attributes & \multicolumn{1}{c}{ Description } & p-Value \\
\hline Crust colour intensity & Degree of perceived brown colour characterising the crust (from low (0) to high (7) intensity) & 0.002439 \\
Crumb colour intensity & Degree of perceived brown colour characterising the crumb (from low (0) to high (7) intensity) & 0.0005065 \\
Air cell size & Average size of the air cells in the bread & $1.615 E-5$ \\
Wheat aroma & Aroma typical of wholemeal wheat flour (from low (0) to high (7) intensity) & NS \\
Roasting cereals aroma & Aroma typical of roasted cereals (from low (0) to high (7) intensity) & NS \\
Saltiness & Degree of perceived salty taste, as a basic taste (from low (0) to high (7) intensity) & NS \\
Bitterness & Degree of perceived bitter taste, caffeine solution (from low (0) to high (7) intensity) & 0.018 \\
Acidity & Degree of perceived acidic taste, as a basic taste (from low (0) to high (7) intensity) & NS \\
Crispiness & Degree of perceived crispiness of the crust (from low (0) to high (7) intensity) & NS \\
Smoothness & $\begin{array}{l}\text { Degree of perceived smoothness of the breads slice surface by lips } \\
\text { (from low (0) to high (7) intensity) }\end{array}$ & 0.0197 \\
\hline Long lasting taste & Period during which overall aroma remains in the mouth (from short (0) to long (7) lasting) & \\
\hline
\end{tabular}


method for separating carotenoids (lutein, alpha-carotenoid and beta-carotenoid) and vitamins (A et E) in food. Finally soluble and insoluble fibres, implicated in textural properties and health benefits properties (lipolytic activities) has been measured using the enzymatic-gravimetric methods with phosphate buffer and three enzyme (heat stable a-amylase, protease and amyloglucosidase). The results are the means of ten repeated measurements.

\subsection{Liking Tests}

For each test the bread was made by one of two local bakers Pierre Delton (Le Pain de Pierre) and Lafuette (Mme VIGIER, Montigny le Bretonneux) one day before the sensory evaluation. It was baked according to their own practices in order to be as close as possible to reality. The questionnaire was implemented at three consumer-oriented events over a two year period. According to the norm defined by the French standardisation association, AFNOR (1988), at least 60 consumers should be interviewed for hedonic tests to obtain significant and reliable results. Finally, as different breads were tasted at each event, the results from one event could not be compared with those from another. For greater clarity and robustness, the study presents the results of the hedonic test implemented at the "fête de l'Humanité" in Paris 2009 and the "Fête du Parc Naturel du Vexin", Jambville 2010, where a sufficient number of respondents were registered (respectively 72 and 169).

The questionnaire asked consumers to rank their preferences on the following sensory traits: external appearance, crumb appearance, aroma, taste, smoothness, chewing and overall preference. A descriptive test was proposed to consumer in order to assess consumers' ability to explain their preferences.

\subsection{Statistical Analyses}

\subsubsection{Sensory Profile}

Analysis of variance (ANOVA) of the descriptive sensory data was performed using the Sensomine R package with panellists as repeated measures. Significant descriptors were selected at $\mathrm{p}<0.05$ using the following ANOVA model:

$\mathrm{Y}=\mu+$ judge + product + session + product $*$ judge + product $*$ session + judge $*$ session $+\varepsilon$.

The panel's power of discrimination was evaluated using the significant effect of product factor. The consensus between panellists has been assessed through the non-significant effect of panellist factor and the product by panellist interaction. Finally repeatability has been measured through the non-significant effect of product by session interaction.

A multi-dimensional profile was then drawn up to view the products’ sensory differences.

\subsubsection{Nutritional Characterisation}

Principal Component Analysis was performed in order to visualise the differences between samples on the nine nutritional descriptors and identified correlated variables.

Six of the samples have been assessed on a sensory and nutritional point of view. To explore the link between sensory and nutritional properties a Multiple Factorial Analyses has been run on the two data type as groups.

\subsubsection{Liking Tests}

A Friedman rank sum test was performed for each descriptor on individual hedonic classification in order to determine the existence of a consensus among consumer and characterised the preferences of group of consensual consumer.

To test the capacity of consumers to perceive differences between breads from diverse genotypes, a PCA was run on the means score of the consumer sensory descriptive data for each product and each descriptor.

\section{Results and Discussion}

\subsection{Sensory Profile}

Of the 11 sensory descriptors, the following 6 attributes were significant in discriminating the products: crust colour, crumb colour, air cell size, roasted aroma, crustiness, wheat grain aroma and long lasting taste (Table 2). There was a consensus on the ranking of the products by the panel (as the panel effect was non-significant) but not on the scaling of the intensity. The panel showed good repeatability and could discriminate for the following descriptors (non-significant product by session interaction effect): crust colour, air cell size, crustiness and long 
lasting taste. The results could be interpreted as a consensus was reached by the panel. A few more sessions would improve the reliability of the results. In order to facilitate visualisation of the discrimination between products, the ellipses given by the panellipse function of the Sensomine R package are provided (Figure 1(a)). Each ellipse was built as a trust-worthy index (for each product, the $95 \%$ closest point of the 500 virtual panels placed this product inside the ellipse). Therefore, when two ellipsesare disjointed, this means that the products were significantly different. The first Principal Component (PC1) explained 55\% of data variability and the second Principal Component (PC2) explained 25\% of the variation, giving a total explained variance of $80 \%$ for the first two principal components (Figure 1). The six discriminant descriptors are well represented on the first plan. Sensory characteristics are of increasing intensity from the left to the right side.

On the right side, breads made from "Odessa" and "Mélange de James" were characterised by the brown colour of their crumb and crust and by its intense roasted aroma (Figure 1(b)). On the left side, "Rouge de Bordeaux" and "Renan" were assessed with low scores for the same attributes. The second dimension oppose dacidic breads (lower right-hand corner) and breads with a long lasting flavour (at the top). Breads characterised by acidic notes were made using "Mélange de James" and "Odessa". Breads with a long lasting flavour were made from "Rouge de Bordeaux" and "Mélange IdF". The bread made with the red variety "Rouge de Bordeaux" was

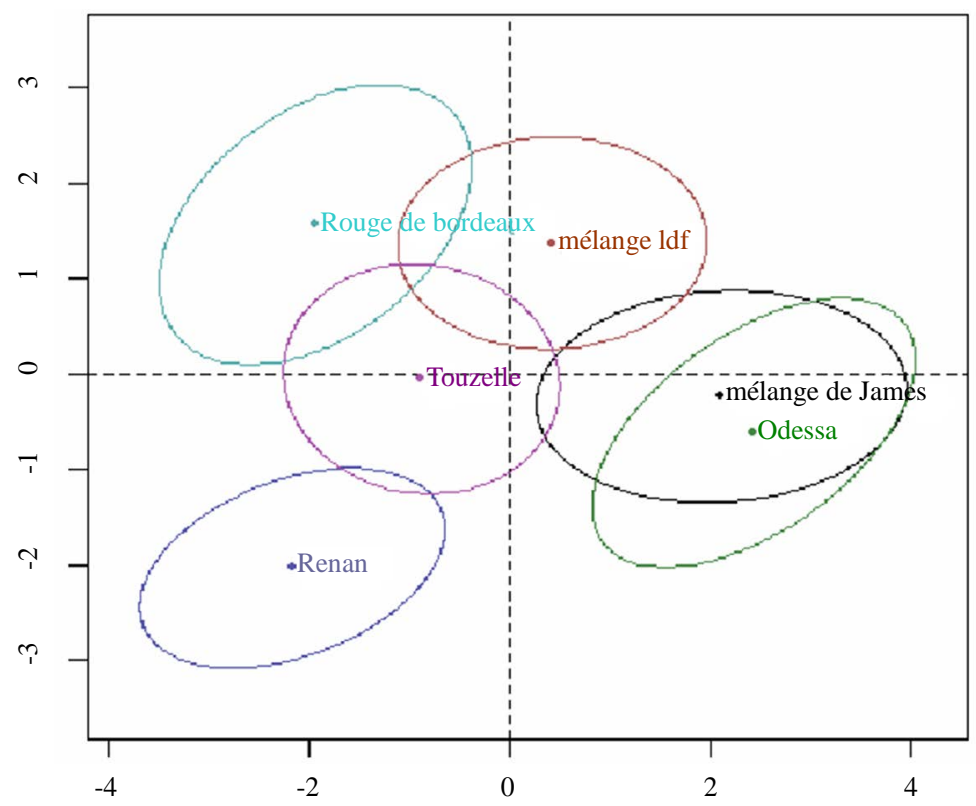

(a)

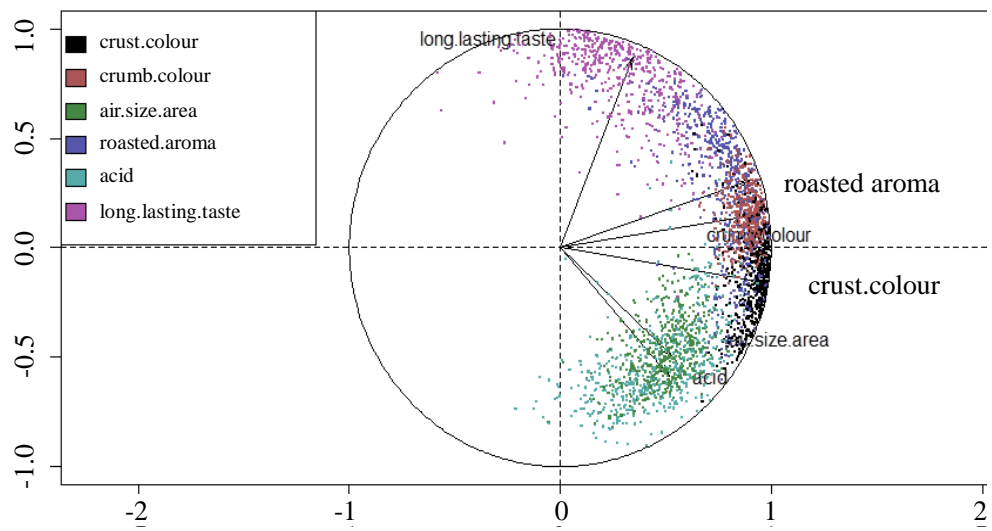

(b)

Figure 1. (a) Confidence ellipse of the mean point of the PCA model of the trained panel sensory evaluation of 6 wheat varieties; and (b) variable factor map. 
significantly different from the "Renan”, "Melange de James” and "Odessa” and was characterised by its long lasting taste. This may be due to the lute in content. "Renan" was the only one that showed no specific sensory characteristics.

\subsection{Nutritional Analyses}

The nutritional composition was examined on all wheat samples (Table 3). Alpha-carotenoid and beta-carotenoid have not been detected in all wheat samples so that they do not figure on the table.

The two first axes of the PCA accounted for $65 \%$ of the variability (Figure 2). The first component separated the wheat grain with high vitamin B1, minerals (iron, magnesium) and total nitrogenous concentration from the light content (Figure 2(b)). The second component opposed wheat grain with high phytate content from grain with low phytate content. The results showed two groups of varieties with specific characteristics.

The first group composed of the varieties "Blé de Gâtines", "Odessa", "Renan" and "Rouge de Bordeaux" was characterised by a higher content of phytate, soluble fibre and vitamin $\mathrm{E}$ and by a low concentration of lutein and insoluble fibre (Figure 2(a)). This group showed a low mineral content which availability might be limited by the high phytate content as the ratio minerals/phytate is close to zero (Table 3). The second group was composed of the following varieties: "Touzelle”, “Chiddamd' Automne” and "Mélange Île de France”. This group was opposed to the first one because of its high lutein and insoluble fibre content and low phytate content. Minerals were in higher proportions and should be more available with regards to phytate concentration.

"Mélange de James" and "Dattel" did not show any specific pattern on the set of measurement scarried out and were not well differentiated on the first two axis of the PCA. Finally, the "Rouge du Roc" variety was characterised by a high content in iron, selenium, magnesium and total nitrogenous matter and a low vitamin E concentration. These minerals were available thanks to the low phytate content (ratio minerals/phytate of 34). This wheat variety has more insoluble than soluble fibre.

Based on these results, it seems surprising that "Rouge du Roc", which was derived a few years ago by the selectionby a farmer of a single plant with awns within a field of "Rouge de Bordeaux", showed a drastically different nutritional composition, particularly in terms of iron, vitamin and nitrogen content. Indeed, genetic diversity of "Rouge du Roc" has been assessed using microsatellite molecular markers and was somewhat different from that of "Rouge de Bordeaux" indicating that the selection of a few spikes within the large variability of "Rouge de Bordeaux" led to a drastic shift in the genetic composition of the "Rouge du Roc" population [14].

Whereas lutein content [10] was found around $1.5 \mu \mathrm{g} / \mathrm{g}$ on varietal mixes with HPLC, our data show concentration lower than $0.1 \mu \mathrm{g} / \mathrm{g}$. Another study on the impact of genotype and environment factor on antioxidant

Table 3. Nutritional analyses of 9 old varieties and 1 pure line. Some samples should not be assesed on gliadin content because of the presence of weevil (NA data). Numbers indicate the group identified by HAC.

\begin{tabular}{|c|c|c|c|c|c|c|c|c|c|c|c|c|}
\hline & $\begin{array}{c}\text { Total } \\
\text { nitrogenousmatte }\end{array}$ & $\begin{array}{r}\text { Gliadin } \\
\text { r(g/100g) }\end{array}$ & $\begin{array}{l}\text { Magnesium } \\
\text { (mg/100g) }\end{array}$ & $\begin{array}{c}\text { Iron } \\
(\mathrm{mg} / \mathbf{1 0 0 g})(\end{array}$ & $\begin{array}{c}\text { Zinc } \\
(\mathrm{mg} / \mathbf{1 0 0 g})\end{array}$ & $\begin{array}{l}\text { Selenium } \\
(\mathrm{mg} / 100 \mathrm{~g})(\end{array}$ & $\begin{array}{c}\text { Lutein } \\
(\mathrm{mg} / \mathbf{1 0 0 g})\end{array}$ & $\begin{array}{c}\text { Vitamin } \\
\text { B1 } \\
(\mathrm{mg} / \mathbf{1 0 0 g})\end{array}$ & $\begin{array}{c}\text { Vitamin } \\
E \\
(\mathbf{m g} / \mathbf{1 0 0 g})\end{array}$ & $\begin{array}{l}\text { Phytate } \\
\text { (mg/100g) }\end{array}$ & $\begin{array}{l}\text { Soluble I } \\
\text { fibres } \\
(\mathrm{g} / \mathbf{1 0 0 g})\end{array}$ & $\begin{array}{c}\text { Insolubles } \\
\text { fibres } \\
\text { (g/100g) }\end{array}$ \\
\hline $\begin{array}{l}\text { Mélange de } \\
\text { James }\end{array}$ & 10.98 & NA & 119.3 & 2.8 & 3.4 & 4.4 & 0.04 & 0.29 & 3.15 & 1150 & 2.8 & 11.8 \\
\hline Touzelle (2) & 10.06 & NA & 124.9 & 2.5 & 3.3 & 3.2 & 0.07 & 0.3 & 2.75 & 873 & 1.3 & 10.4 \\
\hline $\begin{array}{c}\text { Rouge de } \\
\text { Roc }\end{array}$ & 13.57 & 5.05 & 157.5 & 3.9 & 4.9 & 12.4 & 0.04 & 0.39 & 2.25 & 1097 & 1.3 & 9.7 \\
\hline $\begin{array}{l}\text { Chiddam } \\
\text { d'automne } \\
\text { (2) }\end{array}$ & 10.83 & 4.72 & 130.7 & 3.1 & 3.7 & 6.7 & 0.05 & 0.29 & 3.13 & 1021 & 0.7 & 14.3 \\
\hline $\begin{array}{c}\text { Ile de } \\
\text { France (2) }\end{array}$ & 11.09 & 5.43 & 122.9 & 3 & 3.2 & 4.3 & 0.09 & 0.33 & 3.22 & 959 & 2.5 & 10.8 \\
\hline $\begin{array}{c}\text { Blé de } \\
\text { Gâtine (1) }\end{array}$ & 11.33 & 6.42 & 119.3 & 2.8 & 4.6 & 8.5 & 0.03 & 0.3 & 3.95 & 1370 & 2.6 & 10.1 \\
\hline Renan (1) & 11.59 & NA & 134.8 & 2.8 & 4.9 & 0.017 & 0.04 & 0.31 & 4.03 & 1216 & 2.2 & 11.1 \\
\hline $\begin{array}{c}\text { Rouge de } \\
\text { Bordeaux (1) }\end{array}$ & 11.27 & 5.36 & 141.8 & 3 & 5 & 0.006 & 0.04 & 0.31 & 2.36 & 1301 & 3.6 & 11.6 \\
\hline Dattel & 12.3 & NA & 128.3 & 3.3 & 4.1 & 10.6 & 0.05 & 0.34 & 3.27 & 1225 & 3.6 & 9.2 \\
\hline Odessa (1) & 10.67 & 5.33 & 136.4 & 3 & 4.9 & 0.011 & 0.04 & 0.35 & 4.02 & 1245 & 2.6 & 8.6 \\
\hline
\end{tabular}




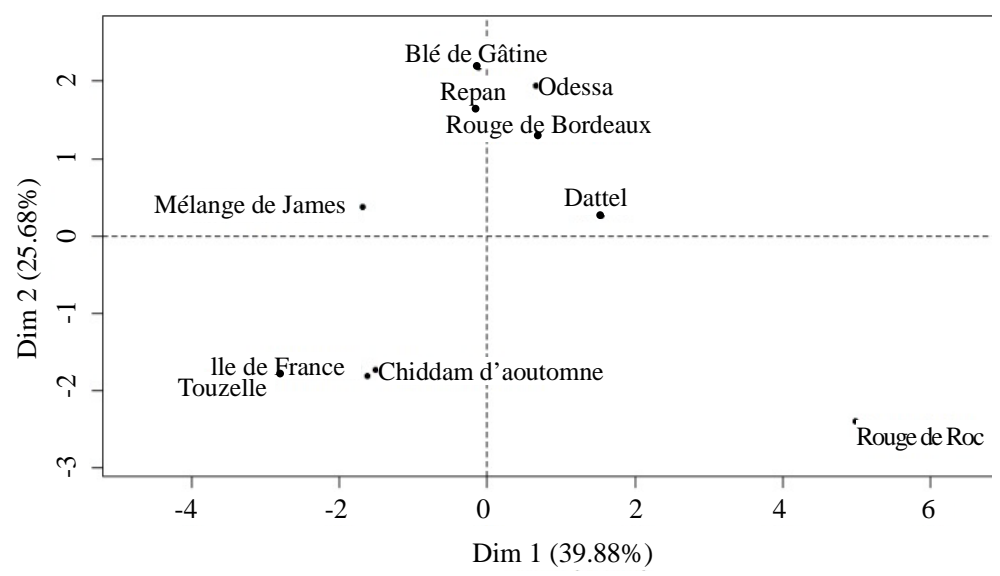

(a)

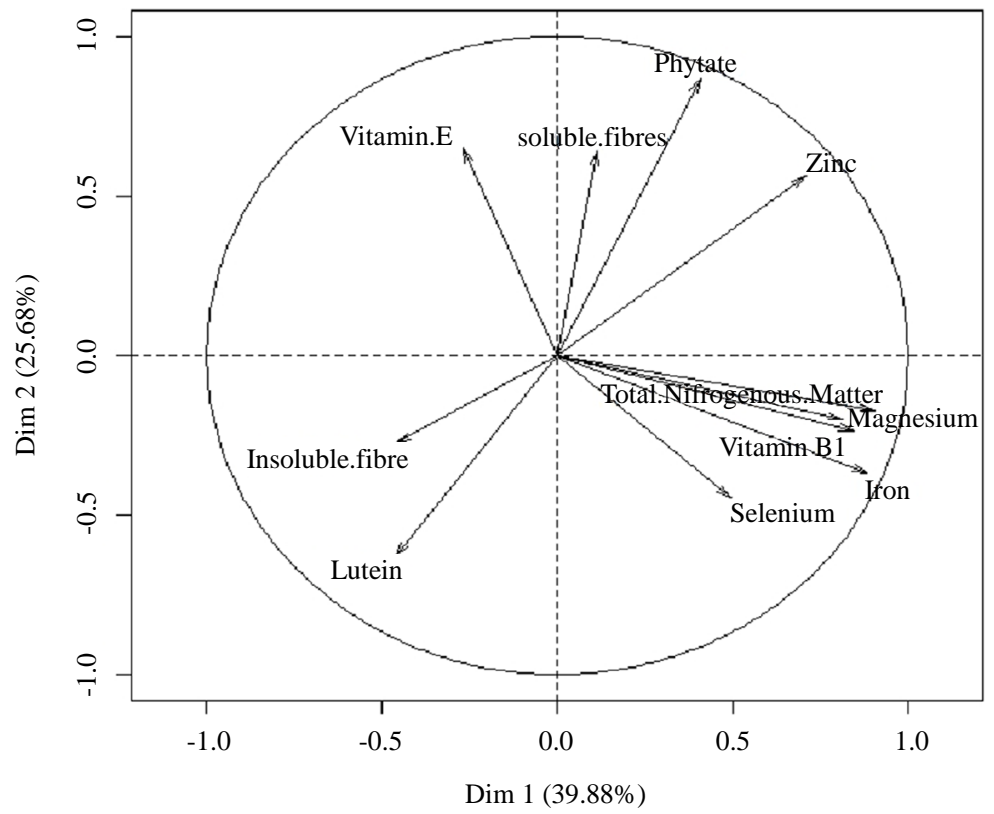

(b)

Figure 2. (a) Individual factor map of the PCA model of nutritional analyses and (b) correlation circle.

properties revealed concentration of lutein between 0.10 and 0.69 [15] which is still higher than values obtains in this study. There is much debate about the reliability of indirect measurement techniques, such as HPLC. For instance, when HPLC was compared with direct measurements of total carotenoid content in pastas using photo acoustic (PA) spectroscopy and colorimetry [16], HPLC was able to detect total carotenoid concentration in only six wheat samples among the 13 samples analysed, whereas PA spectroscopy and colorimetry showed measurable signals for all 13 samples. Indeed, the milling process, which is necessary for HPLC analysis, is known to affect wheat quality. In particular, violent milling might destroy carotenoid pigments. Incomplete extraction and insufficient concentration before analysis are also potential reasons for the absence of HPLC peaks. Here, almost all the samples show alpha-carotene and beta-carotenenot detectable. Moreover, indirect measurement techniques, such HPLC, are costly and time consuming methods, and are not well suited to large scale varietal screening. Direct measurement should therefore be preferred for this purpose [10].

\subsection{Consumer Preferences}

Among the 72 respondents at the "Fête de l'Humanité" in Paris, 2009, 51\% of consumers ranked breads made 
from the variety "Rouge de Bordeaux" highest. Some sensory characteristics could be linked to overall preferences (Figure 3): the "slight bitterness", characteristic of the "Rouge de Bordeaux" variety, or the sheen of the "Touzelle" bread. Result analyses show two consumers' groups which were opposed on the bitterness appreciation. The first group seemed to prefer "Touzelle" and "Rouge de Bordeaux" breads for their dense texture and their sheen. They preferred bread with an intense roasted aroma and dark crumb. The second consumer group favoured the bitterness of Talisman's wheat bread.

The bread made from the "Rouge du Roc" variety was preferred at "Jambville 2010", where $44 \%$ of consumers ranked it highest. Consumers preferred the external appearance of the "Mix of Ile de France and Gâtine" wheat bread but preferred the taste and the textural properties of "Rouge du Roc" wheat bread.

\section{Overall Discussion}

The two first component of the MFA accounted for about $60 \%$ of the variability (Figure 4). The first dimension

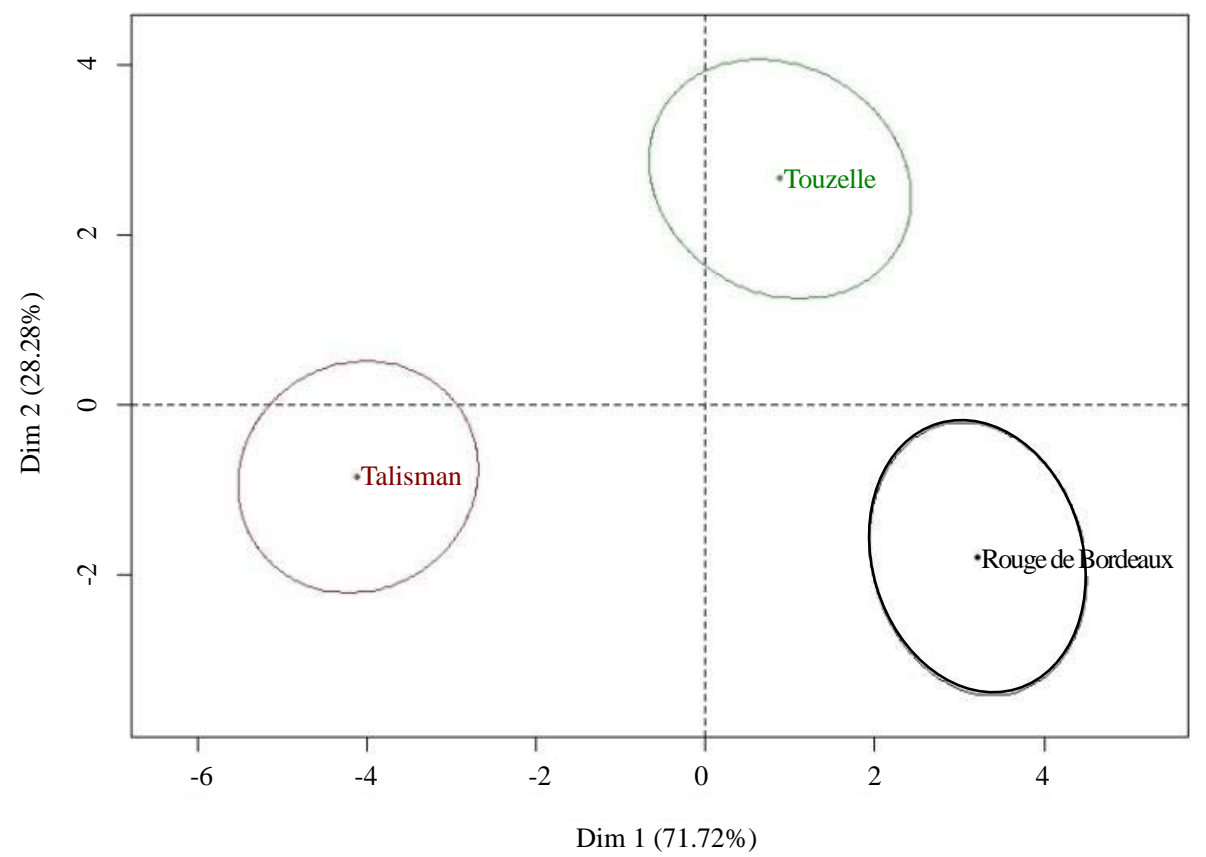

(a)

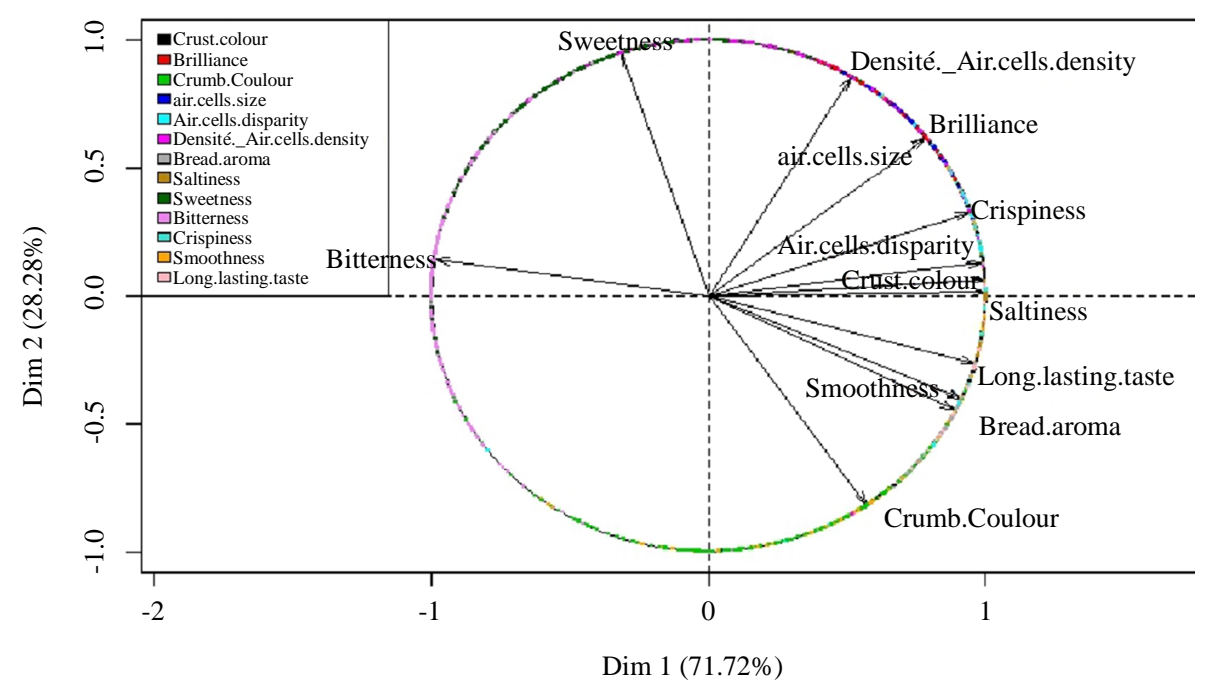

(b) 


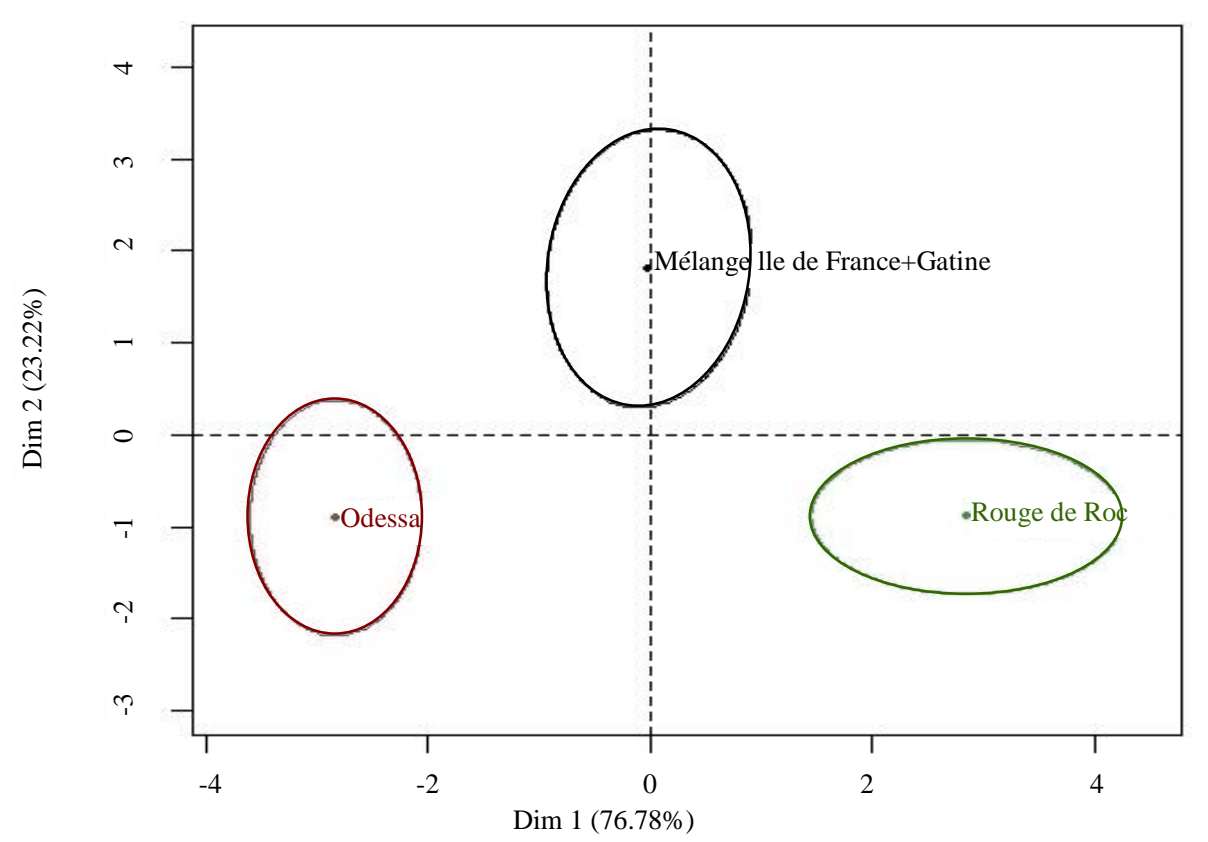

(c)

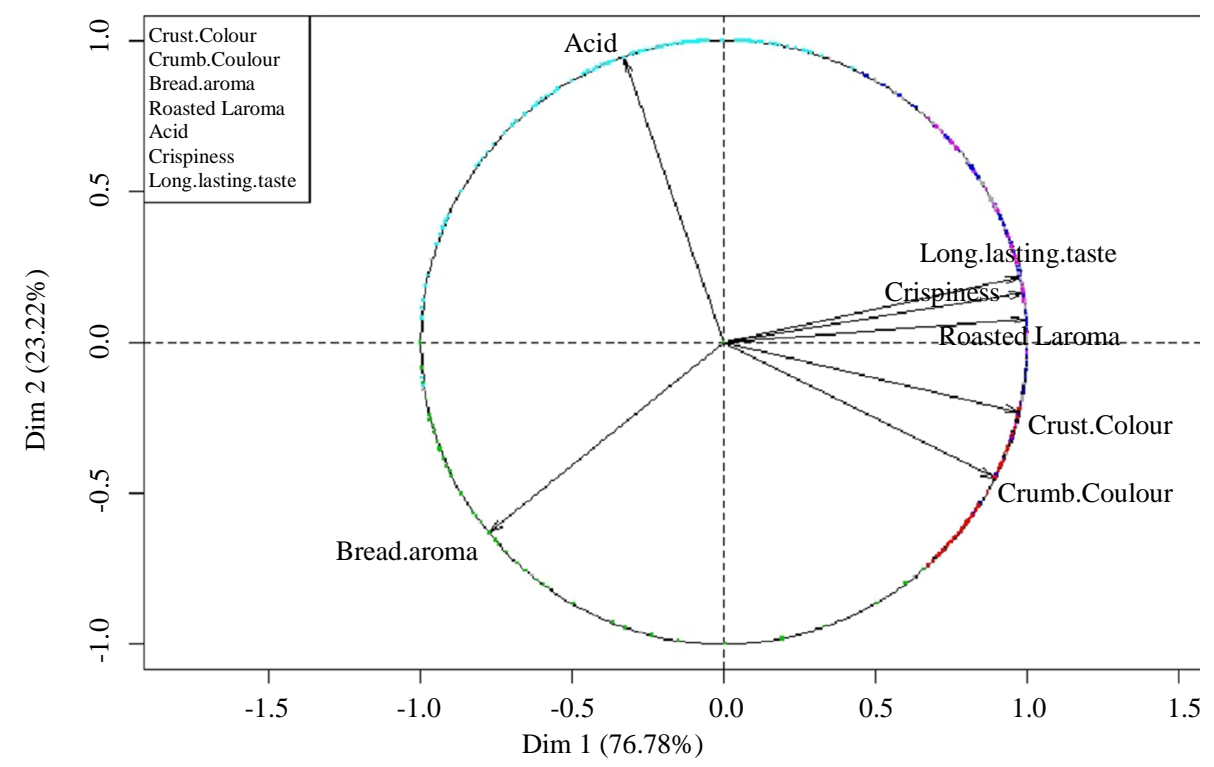

(d)

Figure 3. (a) Confidence ellipse of the mean point of the PCA model of the consumer sensory evaluation of 3 wheat varieties at the "Fête de l'Humanité 2009" event and (b) variable factor map, (c) PCA model of the consumer sensory evaluation of 3 wheat varieties at the "Fête du Parc Naturel Regional du Véxin 2010” event and (d) variable factor map.

is defined by the minerals content (Mg, Zn, Se) with genotypes with high value of $\mathrm{Mg}$ and $\mathrm{Zn}$ on the left side ("Rouge de Bordeaux", “Renan”) and genotype with high value of Se on the right side ("Mélange Idf”, “Mélange de James”) (Figure 4(a)).

The lutein content contributed to this first axes and was correlated with the roasted aroma, the sensory descriptors the most represented on the first dimension (Table 4). The second axes revealed a strong correlation between the sensory attribute "smoothy" and the insoluble fibres content. However, we cannot conclude on the link between nutritional and sensory characteristics from those results as only 6 genotypes have been investigate. 


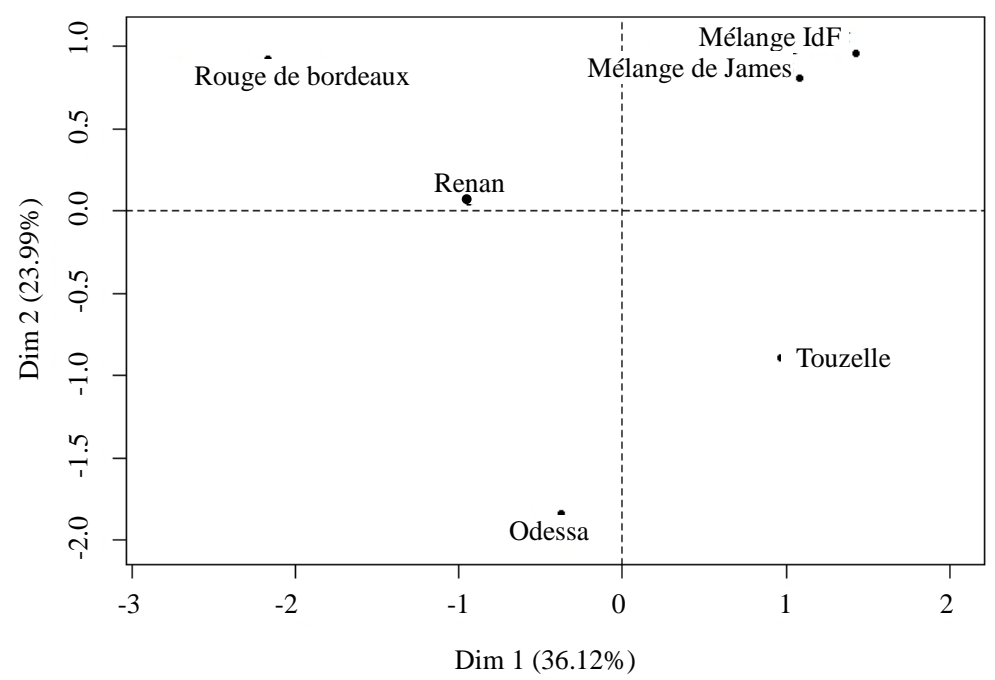

(a)

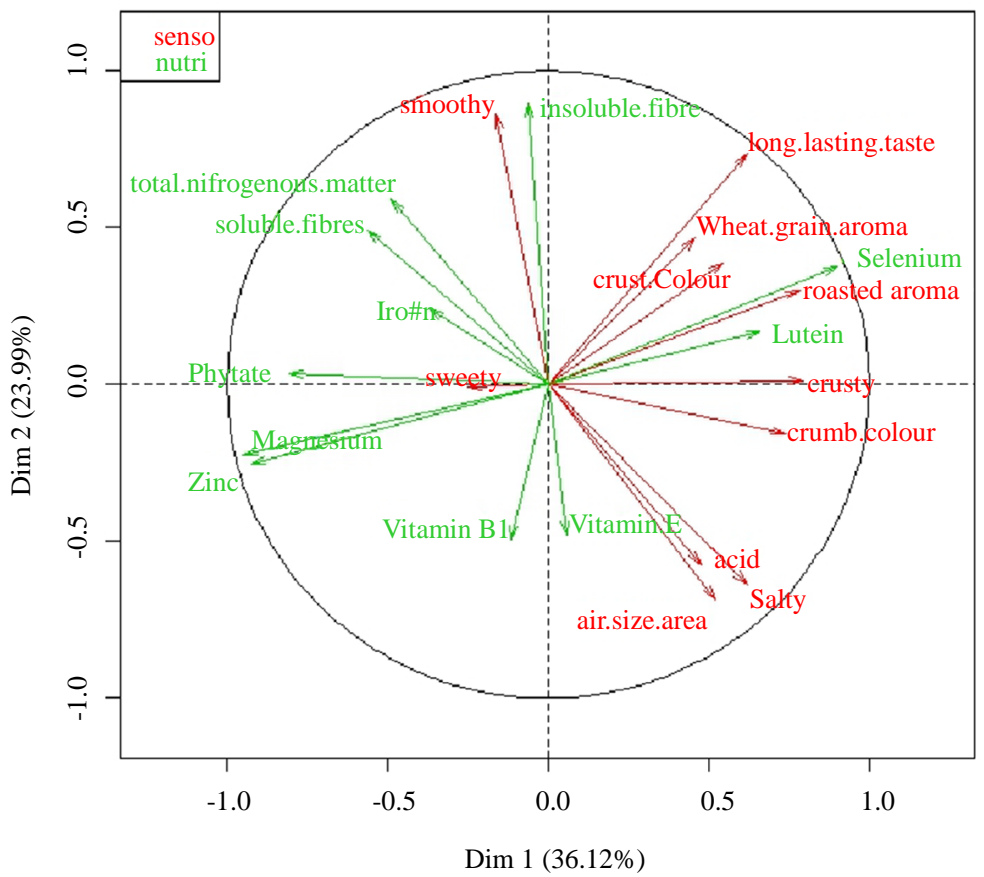

(b)

Figure 4. (a) Individual factor map of the MFA on nutritional and sensory data and (b) correlation circle.

The two accessions with red grain ("Rouge de Bordeaux" and "Rouge du Roc") were perceived as having a long lasting flavour by consumers at the two events and by a trained panel. Nutritional analysis showed specific nutrient content for "Rouge du Roc" with high iron and magnesium content. "Odessa” showed a weak aroma for most of the sensory descriptors when evaluated by consumers but not for the trained panel. Nevertheless, variations in cooking intensity between loaves evaluated by the trained panel were reported and this could explain the more intense roasted aroma of "Odessa”. Consistently, "Odessa" showed a low level of minerals in the nutritional evaluation.

Dark (or red) grain varieties were characterized by their high vanillic and ferullic acid content, which is possibly linked to the vanilla odour [17]. Dark grain colour is due to anthocyanin stored in the pericarp and the testa [18] [19]. Anthocyanins are known to affect sensory characteristics. For example, they have been found positively 
Table 4. Contribution, correlation and p-value of the AFM on nutritional and sensory data as groups (NS: Non Significant).

\begin{tabular}{|c|c|c|c|c|c|c|}
\hline \multirow[t]{2}{*}{ Variable } & \multicolumn{3}{|c|}{ Dim1 } & \multicolumn{3}{|c|}{ Dim2 } \\
\hline & Contribution & Correlation & p-Value & Contribution & Correlation & p-Value \\
\hline Air size area & 3.80 & 0.52 & NS & 9.93 & -0.68 & NS \\
\hline Salty & 5.38 & 0.62 & NS & 8.53 & -0.63 & NS \\
\hline Acid & 3.19 & 0.47 & NS & 6.91 & -0.572 & NS \\
\hline Smoothy & 0.36 & -0.16 & NS & 15.66 & 0.86 & $* *$ \\
\hline Roasted aroma & 8.61 & 0.78 & NS & 1.91 & 0.30 & NS \\
\hline Sweety & 0.87 & -0.24 & NS & 0.001 & -0.007 & NS \\
\hline Crusty & 8.85 & 0.795 & NS & 0.003 & 0.013 & NS \\
\hline Crust colour & 4.12 & 0.54 & NS & 3.18 & 0.39 & NS \\
\hline Wheat grain aroma & 2.96 & 0.46 & NS & 4.64 & 0.47 & NS \\
\hline Long lasting taste & 5.36 & 0.62 & NS & 11.41 & 0.74 & NS \\
\hline Crumb colour & 7.70 & 0.74 & NS & 0.51 & -0.16 & NS \\
\hline Total nitrogenous matter & 2.68 & -0.49 & NS & 5.90 & 0.59 & NS \\
\hline Magnesium & 10.04 & -0.95 & $* *$ & 0.85 & -0.22 & NS \\
\hline Iron & 1.53 & -0.37 & NS & 1.00 & 0.24 & NS \\
\hline Zinc & 9.51 & -0.92 & $* *$ & 1.08 & -0.25 & NS \\
\hline Selenium & 9.07 & 0.90 & $* *$ & 2.38 & 0.38 & NS \\
\hline Lutein & 4.90 & 0.66 & NS & 0.48 & 0.17 & NS \\
\hline Vitamin B1 & 0.15 & -0.11 & NS & 4.11 & -0.49 & NS \\
\hline Vitamin E & 0.04 & 0.06 & NS & 3.88 & -0.48 & NS \\
\hline Phytate & 7.27 & -0.81 & NS & 0.02 & 0.03 & NS \\
\hline Soluble fibre & 3.54 & -0.56 & NS & 4.07 & 0.49 & NS \\
\hline Insoluble fibre & 0.04 & -0.06 & NS & 13.55 & 0.90 & $* *$ \\
\hline
\end{tabular}

correlated to astringency in wine grapes [20]. These results show that consumers can perceive sensory differences that might be associated to dark and light coloured wheat grain.

Breeding for high phytonutrients content appears possible as a highly significant genetic variability and a low genotype by environment interaction for magnesium content for a large set of varieties have been shown [21]. The rate for modern varieties ranged from 600 to $1400 \mathrm{ppm}$ whereas some exotic genotypes showed a higher content of $1890 \mathrm{ppm}$. Zinc content also showed a large genetic effect but genotype by environment interaction was more significant. The nutritional quality of organic wheat bread from diverse origins such as Einkorn or Emmer have been studied and showed a higher content of mineral and phytonutrients than bread wheat varieties [22]. Moreover, significant variation in the total carotenoid content on 48 bread wheat varieties have been found and suggested the possibility of increasing the nutritional value of bread products by selection [10].

The impact of genetic diversity on sensory properties has been assessed on cooked grain [7] [23], flour [24] and bread [25]. The aromatic potential represented by wheat diversity has been studied by implementing a sensory profile on cooked wheat grain from cultivars of different wheat species such as Einkorn, Emmer and Spelt and from bread wheat cultivars [23]. The Einkorn sample showed significant differences on "oat/oatmeal porridge" and "sweet" attributes. In the case of bread, assessing the sensory differences should be carried out after the flour process. 
When studying the sensory properties of breads from modern varieties of white flour type (T55), only very slight differences between varieties were found [25]. This might be due to the choice of varieties which were genetically related and to the flour type, as highlighted in a study on aroma compounds on wholemeal and white wheat flour [24]. This study showed that the wheat flour and the type of flour should be the main factors of wheat bread aroma production and showed a more intense aroma for whole wheat flour. Since bran is characterised by its mineral and phytonutrient content, one hypothesis is that sensory characteristics are related to micronutrients [12]. Alkaline metals, such as potassium, or alkaline earths, such as calcium and magnesium, can be found in wheat in the form of phosphates, carbonates, chlorides and sulphates and may contribute to flavour. Another potential source of flavour variability in wheat breads is lutein, which should affect flavour secondary by limiting the development of hexanal, a compound responsible for flavour and odour problems [11]. The nutritional improvement of bread wheat should therefore contribute to the improvement of the sensory quality of bread.

On a sensory methodology point of view, the use of a consumer panel to objectively evaluate sensory quality should be discussed as it is not common in sensory analysis field. The descriptive consumer test showed the consumers' ability to explain their preferences consistently as they were able to differentiate red accessions at each event. Sensory profile obtained from consumers can show consensus and reproducibility with a large number of consumers [26]. Developing a specific descriptive sensory test for use with consumers will be of interest since such a test would offer a quicker and less expensive option than conventional profiling with a trained panel. Moreover, it is a way of bringing consumers closer to the farmers and the agricultural sector and of making them aware of the issues of agricultural production. Such methods are being developed, one of the most promising being napping. It relies on identification of the sensory distances perceived and offers greater flexibility [27].

\section{Conclusions}

The evaluation of the sensory impact of wheat varieties on bread is a complex task as all the varieties studied have to be grown in the same location, in the same year and under the same farming practices to eliminate environmental effects. Since the baking process has a great impact on the sensory qualities, bread from different varieties must be baked by the same baker in a single batch. This study focuses on the sensory characteristics of a small set of population varieties but further investigations are needed on individual impact and interaction of bread main parameters.

Differences among varieties were perceived even after flour processing by both experts and consumers. It seems that nutritional and sensory value of wheat bread could be improved by selecting specific genotypes.

A large number of landraces and historic varieties can be obtained from the national and international gene banks [13]. Some of them, including "Rouge de Bordeaux", "Rouge du Roc”, “Touzelle”, "Mélange de James”, and several others that were tested in this study, have been grown, selected and multiplicated by farmers for several years to adapt them to their environments and agricultural practices. They are now cultivated on larger plots and assessed in participatory plant breeding programs [28]. There is a strong demand for more information on their baking, sensory and nutritional qualities.

This study paves the way for a number of new initiatives in France that experiment the sensory qualities of breads obtained from a large range of wheat varieties. A database including genotype by environment analyses is needed to help breeding efforts for quality.

\section{Acknowledgements}

The authors would like to thank the members of "Nature \& Progrès" for their contribution to the implementation of consumer tests and specially Adèle Hospital who participate to all the consumer tests, our baker partners for their involvement in the experiments. This work has been conducted with the financial support of the Région Ile de France (Partenariat Institutions Citoyens pour la Recherche et l'Innovation, PICRI 2007-2011).

\section{References}

[1] Bordes, J., Branlard, G., Oury, F.X., Charmet, G. and Balfourier, F. (2008) Agronomic Characteristics, Grain Quality and Flour Rheology of 372 Bread Wheats in a Worldwide Core Collection. Journal of Cereal Science, 48, 569-579. http://dx.doi.org/10.1016/j.jcs.2008.05.005

[2] Lammerts van Bueren, E.T., Jones, S.S., Tamm, L., Murphy, K.M., Myers, J.R., Leifert, C. and Messmer, M.M. (2011) 
The Need to Breed Crop Varieties Suitable for Organic Farming, Using Wheat, Tomato and Broccoli as Examples: A Review. NJAS—Wageningen Journal of Life Sciences, 58, 193-205. http://dx.doi.org/10.1016/j.njas.2010.04.001

[3] Torri, L., Migliorini, P. and Masoero, G. (2013) Sensory Test vs. Electronic Nose and/or Image Analysis of Whole Bread Produced with Old and Modern Wheat Varieties Adjuvanted by Means of the Mycorrhizal Factor. Food Research International, 54, 1400-1408. http://dx.doi.org/10.1016/j.foodres.2013.09.045

[4] Katina, K., Heiniö, R.L., Autio, K. and Poutanen, K. (2006) Optimization of Sourdough Process for Improved Sensory Profile and Texture of Wheat Bread. LWT, 39, 1189-1202.

[5] Khilberg, I., Johansson, L., Kohler, A. and Risvik, E. (2004) Sensory Qualities of Whole Wheat Pan Bread-Influence of Farming System, Milling and Baking Technique. Journal of Cereal Science, 39, 67-84. http://dx.doi.org/10.1016/S0733-5210(03)00067-5

[6] Ploeger, A., Röger, M., Lueck, L. and Leifert, C. (2008) Sensory Evaluation of Processed Wheat from a Defined FieldTrial (Quality Low Input Food). IFOAM Organic World Congress, Modena.

[7] Starr, G., Bredie, W.L.P. and Hansen, A.S. (2013) Sensory Profiles of Cooked Grains from Wheat Species and Varieties. Journal of Cereal Science, 57, 295-303. http://dx.doi.org/10.1016/j.jcs.2012.11.014

[8] Štepánková, R., Kofronová, O., Tucková, L., Kozáková, H., Cebra, J.J. and Tlaskalová-Hogenová, H. (2003) Experimentally Induced Gluten Enteropathy and Protective Effect of Epidermal Growth Factor in Artificially Fed Neonatal Rats. Journal of Pediatric Gastroenterology and Nutrition, 36, 96-104.

[9] Meydani, M. (2002) Antioxidants in the Prevention of Chronic Diseases. Nutrition in Clinical Care, 5, 47-49. http://dx.doi.org/10.1046/j.1523-5408.2002.00002.x

[10] Leenhardt, F., Lyan, B., Rock, E., Boussard, A., Potus, J., Chanliaud, E. and Remesy, C. (2006) Genetic Variability of Carotenoid Concentration, and Lipoxygenase and Peroxidase Activities among Cultivated Wheat Species and Bread Wheat Varieties. European Journal of Agronomy, 25, 170-176. http://dx.doi.org/10.1016/j.eja.2006.04.010

[11] Institut National de la Boulangerie Pâtisserie (2003) Supplément technique INBP n 83-Le goût du pain.

[12] Fujino, Y., Kuwata, J., Mano, Y. and Ohnishi, M. (1996) Other Grain Components. Cereal Grain Qual. Kettlewell PS, 305-307.

[13] Roussel, V., Leisova, L., Exbrayat, F., Stehno, Z. and Balfourier, F. (2005) SSR Allelic Diversity Changes in 480 European Bread Wheat Varieites Released from 1840 to 2000. Theoretical and Applied Genetics, 111, 162-170. http://dx.doi.org/10.1007/s00122-005-2014-8

[14] Thomas, M., Demeulenaere, E., Dawson, J.C., Khan, A.R., Galic, N., Jouanne-Pin, S., Remoue, C., Bonneuil, C. and Goldringer, I. (2012) On-Farm Dynamic Management of Genetic Diversity: The Impact of Seed Diffusions and Seed Saving Practices on a Population-Variety of Bread Wheat: On-Farm Crop Metapopulation of Bread Wheat. Evolutionary Applications, 5, 779-795.

[15] Lv, J., Lu, Y., Niu, Y., Whent, M., Ramadan, M.F., Costa, J. and Yu, L. (2013) Effect of Genotype, Environment, and Their Interaction on Phytochemical Compositions and Antioxidant Properties of Soft Winter Wheat Flour. Food Chemistry, 138, 454-462. http://dx.doi.org/10.1016/j.foodchem.2012.10.069

[16] Dóka, O., Bicanic, D., Buijnsters, J.G., Spruijt, R., Luterotti, S. and Végvári, G. (2010) Exploiting Direct and Indirect Methods for the Estimation of the Total Carotenoid Concentration in Dried Pastas. European Food Research and Technology, 230, 813-819. http://dx.doi.org/10.1007/s00217-010-1222-x

[17] Liu, Q., Qiu, Y. and Beta, T. (2010) Comparison of Antioxidant Activities of Different Coloured Wheat Grains and Analysis of Phenolic Compounds. Journal of Agricultural and Food Chemistry, 58, 9235-9241. http://dx.doi.org/10.1021/jf101700s

[18] Guo, Z., Xu, P., Zhang, Z., Wang, D., Jin, M. and Teng, A. (2011) Segregation Ratios of Colored Grains in Crossed Wheat. Australian Journal of Crop Science, 5, 589-594.

[19] Zeven, A.C. (1991) Wheats with Purple and Blue Grains: A Review. Euphytica, 56, 243-258. http://dx.doi.org/10.1007/BF00042371

[20] Brossaud, F., Cheynier, V. and Noble, A.C. (2001) Bitterness and Astringency of Grape and Wine Polyphenols. Australian Journal of Grape and Wine Research, 7, 33-39. http://dx.doi.org/10.1111/j.1755-0238.2001.tb00191.x

[21] Oury, F.X., Leenhardt, F., Rémésy, C., Chanliaud, E., Duperrier, B., Balfourier, F. and Charmet, G. (2006) Genetic Variability and Stability of Grain Magnesium, Zinc and Iron Concentrations in Bread Wheat. European Journal of Agronomy, 25, 177-185. http://dx.doi.org/10.1016/j.eja.2006.04.011

[22] Hussain, A. (2012) Quality of Organically Produced Wheat from Diverse Origin. Swedish University of Agricultural Sciences, Uppsala.

[23] Løje, H., Møller, B., Laustsen, A. and Hansen, Å. (2003) Chemical Composition, Functional Properties and Sensory Profiling of Einkorn (Triticum monococcum L.). Journal of Cereal Science, 37, 231-240. 
http://dx.doi.org/10.1006/jcrs.2002.0498

[24] Czerny, M. and Schieberle, P. (2002) Important Aroma Compounds in Freshly Ground Wholemeal and White Wheat Flour-Identification and Quantitative Changes during Sourdough Fermentation. Journal of Agricultural and Food Chemistry, 50, 6835-6840. http://dx.doi.org/10.1021/jf020638p

[25] Brabant, C., Fossati, D. and Kleijer, G. (2007) Influence de la variété de blésur le goût du pain. Revue Suisse d'Agriculture, 39, 101-108.

[26] Husson, F., Le Dien, S. and Pagès, J. (2001) Which Value Can Be Granted to Sensory Profiles Given by Consumers? Methodology and Results. Food Quality and Preference, 12, 291-296. http://dx.doi.org/10.1016/S0950-3293(01)00014-3

[27] Perrin, L., Symoneaux, R., Maître, I., Asselin, C., Jourjon, F. and Pagès, J. (2008) Comparison of Three Sensory Methods for Use with the Napping ${ }^{\circledR}$ Procedure: Case of Ten Wines from Loire Valley. Food Quality and Preference, 19, 1-11. http://dx.doi.org/10.1016/j.foodqual.2007.06.005

[28] Rivière, P., Goldringer, I., Berthellot, J.F., Galic, N., Pin, S., De Kochko, P. and Dawson, J.C. (2013) Response to Farmer Mass Selection in Early Generation Progeny of Bread Wheat Landrace Crosses. Renewable Agriculture and Food Systems, 1-12. http://dx.doi.org/10.1017/S1742170513000343 
Scientific Research Publishing (SCIRP) is one of the largest Open Access journal publishers. It is currently publishing more than 200 open access, online, peer-reviewed journals covering a wide range of academic disciplines. SCIRP serves the worldwide academic communities and contributes to the progress and application of science with its publication.

Other selected journals from SCIRP are listed as below. Submit your manuscript to us via either submit@scirp.org or Online Submission Portal.
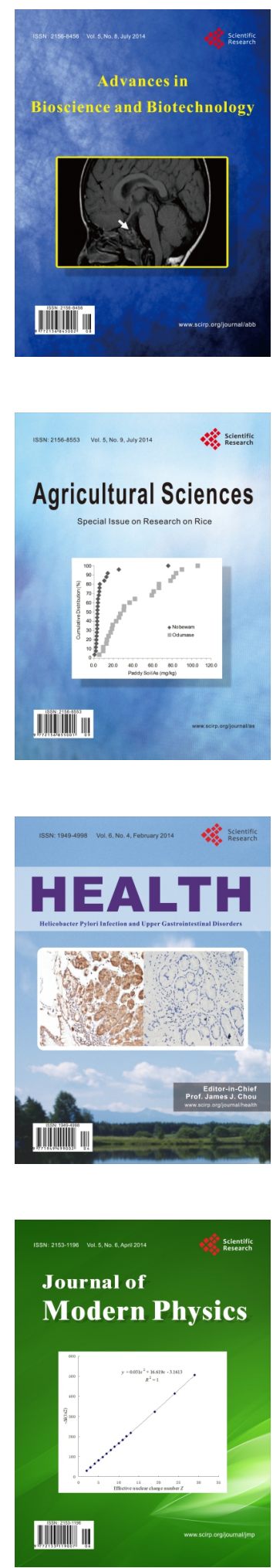
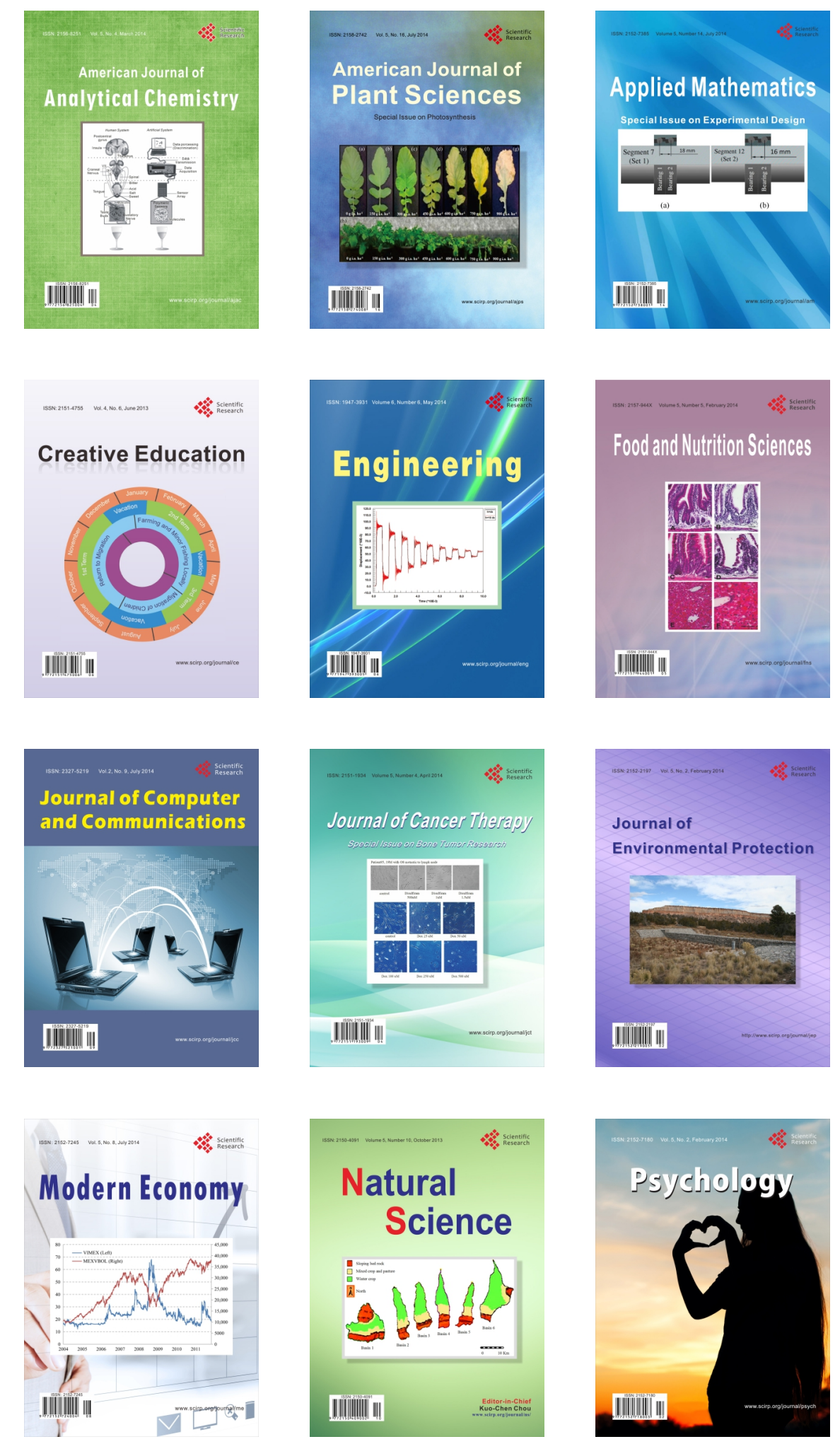